\title{
The Role of Government in Preservation and Distribution of Muslim Scripture: From Written to Digital Quran
}

\author{
$1^{\text {st }}$ Widyawati ${ }^{1}, 2^{\text {nd }}$ Munir $^{2}$ \\ \{vidyamoenir@gmail.com ${ }^{1}$, muniramuin@gmail.com ${ }^{2}$ \} \\ UIN Sunan Gunung Djati, Faculty of Sharia and Law, Bandung, Indonesia ${ }^{1}$, UIN Sunan Gunung \\ Djati, Faculty of Ushuluddin, Bandung, Indonesia ${ }^{2}$
}

\begin{abstract}
Indonesia is a country with the most populous Muslim in the world. However, this country is not based on Islam; rather it prefers to be a Pancasila state. This fact, no doubt, leads to a question of how the state manages the religious life of its majority citizen, especially in terms of their scripture, al-Quran. This research raises such question, with specific reference to government policies in terms of preservation and distribution of the Quranic text. This research concludes that although it is not from the very beginning, the state had indeed concern about the policies of preservation and distribution of Quranic text. Those policies took form in regulations and provisions that bind all interest-parties in order to preserve and venerate the Quran. To arrive at the conclusion above, this research used content analysis method accompanied with several approaches. As for the data, this research utilized primary and secondary sources gathered through different methods. The data collection was conducted through library research and interview with those competents in the field, especially the officials at Committee of Correction of Quranic Text (Lajnah Pentashihan Mushaf Al-Quran, LPMQ).
\end{abstract}

Keywords: Quran, government, LPMQ, digital Quran, tashih.

\section{Introduction}

Quran is a holy book which from its early revelation claims to be words of God that are authentic and free from any distortion (Quran, 6:115). In one of its verses, for example, this book argues that it is revealed by God and its perfection and authenticity is insured by Him. In another verse it is stated that this book will not suffer from any change and distortion as the other previous books (Quran, 15:9; 4:46; 5:13). Furthermore, it is reported in a prophetic tradition (hadith) that the Prophet Muhammad was ordered to recite the Quran under supervision Gabriel in the every month of Ramadan [1].

Attempts at preservation of the Quranic authenticity continued to be carried out in the period of Rashidun caliphs [2]-[4] and continued from the following periods to the present. The Kingdom of Saudi Arabia, for example, in its attempt to preserve and distribute the Quran, has established a specific institution called Mujamma' Malik al-Fahd li-Tiba 'at alMushaf al-Sharif [5]. This institution is responsible for printing and distribution of Quran into all over the world. In addition, it continues to develop translation of the book into diverse 
languages of different peoples. It is not surprising that this institution is in avant-garde in preservation and distribution of the Quran in the world.

Although it is not an Islamic state, like Saudi Arabia, Indonesian government also insures, and is responsible for religious practices conducted by its citizen, including Muslim religious life. As majority, it is not strange if Muslims get a great attention from the state especially in religious affairs, especially in terms of their scripture, Quran.

To meet this, the state has established Lajnah Pentashihan Mushaf Al-Quran (LPMQ, Institute for Verification of Quranic text) under Ministry of Religious Affairs (MORA). Through this institute, the state expects the need of Muslims towards the Quran can be well and rightly fulfilled. Furthermore, Quranic text distributed to Muslim society is free from any mistake and defect that leads to disturb the authenticity of the book and bring about a doubt among them. Studies in this topic have been conducted by a number of scholars such as Enang Sudrajat [6], Abdul Hakim [7], Jayusman [8] and so on.

This paper discusses the role of LPMQ in preserving and distributing the Quran to Muslim society, as well as its role in developing their understanding of this scripture, including the provision of digital application of the Quran. It is intended to describe the policies issued by the government through LPMQ on this scripture.

\section{Methodology}

This paper uses content analysis as method followed with political and theological approaches. As Earl Babbie [9] argues, content analysis is applicable to newspaper, magazine, speeches, documents, laws and constitutions, and even platform of organizations. Furthermore, political approaches are necessary because government policies on the Quran are parts of the state practices towards this scripture, whereas theological approaches are used since the Quran is the core of Islam which cannot be separated from doctrines of this religion. As for the data, this paper draws on the regulations issued by Ministry of Religious Affairs as well as related works on the issues under discussion. The data are obtained through documentary study and in-depth interviews with the stakeholders of LPMQ.

\section{Result and Discussion}

\subsection{Government Policies}

The concern of Indonesian government with the Quran did not commence since its independence in 1945. Rather, its concern started with Regulation of Minister of Religious Affairs Number 1 issued in 1957 [10]. One of considerations underlying this regulation is that it is a kind of implementation of the first principle of Pancasila, "Belief in One God" (Ketuhanan Yang Maha Esa). In effect, this principle implies that the state does not merely recognize the faiths of Indonesian peoples, it is also responsible to facilitate them in practicing their faiths. Therefore, the Quran-Muslim scripture - should be placed in its due and preserved from any mistake.

However, there is no institution that is authoritative and responsible for this task in Indonesian Muslim society. This is very different from Christianity which has a specific institution for this task known as Lembaga Alkitab Indonesia (Indonesian Bible Society). This 
institution played an important role in translating and distributing bibles in Bahasa Indonesia and other local languages. For this reason, such institution is necessary to insure the authenticity and validity of the Muslim scripture [10].

According to this regulation, this institution was named Majelis Musahhihin (Council of Verification). Since the Quran will be printed and distributed to Muslims, this text should be free from any mistake, and it is this task that this council should insure. Initially, this institution was not informal in that it was not included into a formal structure in ministry. Moreover, its members were the ulama known for their knowledge and memory of the Quran (Quranic scholars) from different backgrounds.

In general, the content of this regulation can be classified into two categories: administrative and substantive. By administrative we mean prerequisites necessary for publication of the Quranic text, including permission, materials used to print, and so on. On the other hand, we mean by substantive prerequisites are verification of the huffazh (scholars who memorized the Quran), using the Arabic letters for the arts of reciting the Quran and so on.

From the above discussion it can be stated that the Regulation of Ministry of Religious Affairs Number 1 of 1957 is a milestone of government concern with the Muslim scripture. Besides, it is this regulation that served a basis for progressive concern of the government toward the Quran as will be seen in the next regulations.

In 1959, Ministry of Religious Affairs issued another Regulation which dealt specifically with this institution. Based on this regulation, this institution was transformed from Majelis Musahhihin into Panitia Pentashih Mushaf Al-Quran (Committee of Verification of Quranic Text). Moreover, this regulation explicitly mentions that this institution should consist of nine experts in Quranic studies. However, the task they hold is responsibly to preserve the authenticity of Quran and to ensure that there is no mistake in the printed text of Quran. No less important is that this institution should oversee the distribution of Quranic text in Indonesia [11].

However, the need of Muslims towards their scripture is not limited to the availability of its text. Rather, they need to develop their understanding of the Quran so that they can implement its tenets in their life. In response to this need, MORA issued decrees number 91 of 1962 and number 63 of 1963 on Institute of Translation and Interpretation of Holy Quran. Under direction of Prof. Mr. Soenarjo, this institute published Al-Quran dan Terjemahnya (The Quran and Its Translation) in 1972 and its complete edition in 1980 [12].

In 1982, MORA expanded the task of this institute through Regulation number 1 of 1982 on Lajnah Pentashih Mushaf al-Quran [13]. According to this regulation, LPMQ had higher status than before due to the fact that it was an auxiliary board of Minister of Religious Affairs in terms of verification of Quranic text, its translation and interpretation, recording and publication in different forms, including in an electronic manner. This is because the need of Muslims towards their scripture also developed in line with the development of technology. Therefore, this institute developed a number of divisions necessary to meet the above task.

Those divisions include: (1) Division of Tashih; (2) Division of Quranic text in Braille form; (3) Division of Quranic Translation and Interpretation; and (4) Division of Quranic Recording and Electronic forms. From these divisions, it seems that LPMQ meets specially the need of blind Muslims on the one hand and those Muslims familiar with electronic media on the other towards the Quran. Moreover, this development shows that the government—via MORA - is really aware of the need of Muslims in reference to their scripture [13].

As mentioned previously, LPMQ has translated the Quran into Bahasa Indonesia in order that Indonesian Muslims understand their scripture. However, this translation is supposed to 
be outdated that it needs a revision. To respond this, MORA through Regulation number 230 of 2003 formed a new team for refinement of Quranic translation and interpretation. The main objective of this team is to revise and make additional notes necessary for and relevant to the completion of this translation and interpretation [14].

There is a significant change in LPMQ when MORA issued Regulation number 3 of 2007 [15]. What is significant in this regulation is that LPMQ is not responsible only for verification (tashih) of Quranic text, it is also responsible for the translation of Quranic text that will be distributed to Muslim society. In addition, the Regulation stipulates that LPMQ should facilitate Muslims for understanding the teachings of their scripture through its translation and interpretations from diverse dimensions. Above all, this institute has an additional and new task, i.e. to maintain and preserve Islamic culture in Indonesia. It seems that this last task is irrelevant to LPMQ, but it will be clear that Islamic culture here can be interpreted to include anything related to the Quran, such as calligraphy, manuscripts, and so on [16].

Based on this regulation, LPMQ at the present has three different divisions with their own different responsibilities. First, division of tashih, which is responsible for correction of Quranic text, its translation as well as its interpretation in variety of forms. Second, division of Quranic studies, which is responsible to develop, study and publish Quranic text, its translation and interpretation. Third, division of Bayt al-Quran and Documentation whose main task is to preserve and manage museum called Bayt al-Quran [15].

From the above discussion it is clear that the government-through LPMQ - is highly concerned with the Quran for Muslims. This concern developed gradually from its attention to Quranic text to Muslim understanding of this scripture through its translation, interpretation and study of its main teachings.

\subsection{Mechanism for Verification of Quranic Text}

As previously alluded to, the main task of LPMQ is to verify the Quranic text, its translation and interpretation that will be distributed to Muslim society. In this section, this paper discusses in brief the mechanism used by LPMQ to meet its task, especially in terms of substantive requirements [17].

First, the manuscript will be verified by the scholars or experts of Quranic text. Second, the manuscript that had been verified by one scholar or expert, it will be verified by another scholar. This cross-verification is not conducted only once, but many times to insure that the manuscript will not suffer from any mistake. Another way to verify the manuscript is through reading and listening where one is reading the manuscript while the others are listening and verifying it. In addition, verification can be carried out through listening to recording of Quranic recitation in which the scholars listen to this recording and at the same time verify the manuscript.

Third, after cross-verification was conducted many times, there is list of mistakes and their correction in two pieces, one for the publisher that proposed the manuscript and another for LPMQ. Fourth, the publisher should make correction as recommended by LPMQ. Fifth, the publisher should come to LPMQ with the corrected manuscript to be cross-verified once again. Sixth, if the manuscript is in line with the listed correction, LPMQ will hand over the manuscript to the publisher to publish an example. Seventh, the sample of printed manuscript will be verified again by LPMQ, and if there is no mistake, then LPMQ will issue a certificate for the publisher to print the manuscript. Eight, it is based on this certificate that the publisher can publish the manuscript legally for public purpose in accordance with number proposed to LPMQ. 
Although there are some other steps to follow for the publisher, but they are not so substantial that we are needless to explore here. This mechanism is also applicable to cassette recording, CD-Rom, and to other forms of electronic version. According to Ahsin Sakho, process of certification of manuscript takes long enough time, about two months, if every step mentioned above runs well. This is conducted to preserve the authenticity of the Quran on the one hand and to prevent any doubt on this scripture among Muslims. It is for this reason that he suggests the publisher to have its manuscript verified by its own scholar or expert before proposed to LPMQ, so that the process at this institute does not take too long time [18].

What this section has discussed shows that LPMQ has been seriously concerned with authenticity of the Quran and insured that this scripture has been verified well before its publication and distribution to Muslim society. This also shows that the government - through LPMQ - paid serious attention to Muslim religious life, especially in terms of their scripture.

\subsection{Digital Quran}

As alluded to previously, the task of LPMQ is not limited to verification of the Quran. It is also responsible to meet the need of Muslims towards their scripture. With the development of technology, LPMQ provides the Quran in digital form. This Quran has been launched in August 28, 2016, by Minister of Religious Affairs, Lukman Hakim Saifuddin [19].

In that occasion he stated, "I hope that this first step of launching this application can be developed in much better manner in both technical terms and contents so that it can facilitate Muslim society in widest sense for reading and studying the Quran.'[19] Moreover, he adds that an attempt at preservation of the authenticity of the Quran should not limited to its written form or text, it is also important to preserve its contents. In the digital era which is full of openness, any information will be easily accepted by society, including religious understanding.

According to him, information is not always of positive content. It can contain hate expression and violence as can be found in social media, and this is difficult to prevent. Therefore, the government attempts to provide literatures on understanding and interpretation of the Quran in moderate and tolerant way, and respectful to diversity of religion through a number of media, both in printed and electronic ones. On the basis of this situation, "Today, I am very happy that along with the international seminar on the Quran to commemorate its first revelation 1.450 years before, Ministry of Religious Affairs presents to society digital application of the Quran companied with its translation and interpretation.’[19]

On the other hand, the head LPMQ, Muchlis Hanafi, explains that the users of smartphones can download the digital application of the Quran at Google Play Store, as well as at App-Store and Windows Phone Store.

Hanafi said that the first generation of this application provides the Quranic text completely accompanied with its translation. Moreover, it also contains interpretation in two different versions: tahlili (detailed interpretation) and short ones. He adds that this application has another feature, that is, murattal recitation of the Quran by Syekh Mahmud Khalil alHushary [20].

Hanafi explains further that this application utilizes Indonesian standard of Quranic text (Mushaf Al-Quran Standar Indonesia) in terms of method of writing, symbols and so on. As for the translation, this application uses Al-Quran dan Terjemahnya (Quran and Its Translation) composed by Ministry of Religious Affairs, while the interpretation, especially in tahlili version, is based on Al-Quran dan Tafsirnya (Quran and Its Interpretation) which is also composed by MORA. On the other hand, short interpretation available in this application is based on Tafsir Ringkas Al-Quran Al-Karim as a product of study of Quranic interpretation 
conducted by MORA and Center for the Study of Quran (Pusat Studi Al-Quran), Jakarta. He promised that this application will be developed and added with new features, such as thematic and scientific interpretation of the Quran, the conditions of Quranic revelation ( $a s b a b$ $a l-n u z u l)$ and so on [20].

\section{Conclusion}

Some conclusions can be drawn from the above discussion. Although it is not an Islamic state, Indonesia is seriously concerned with Muslim scripture through LPMQ. This institute has played an important role in provision and distribution of the Quran in Muslim society. Moreover, it is responsible for preservation of Quranic authenticity, and at the same time for the development of Muslim understanding of their scripture by providing the translation and interpretation of this scripture. In a nutshell, it can be argued that the state, although it is not Islamic, cannot put aside the faith of its citizen, especially in terms of their scripture.

Acknowledgements. This paper in conjuction with the 2nd International Conference on Quran-Hadith, Information Technology and Media: Challenges and Opportunities (ICONQUHAS 2018).

\section{References}

[1] M. ibn I. Bukhārī, Șahīh al-Bukhārī. Beirut: Dar al-Kutub al-'Ilmīyah, 2014.

[2] C. Gilliot, "Creation of a fixed text," in The Cambridge Companion to the Qur'an, J. D. McAuliffe, Ed. Cambridge: Cambridge University Press, 2006, pp. 41-58.

[3] Badaruddin, "Garansi Kemurnian Ayat-Ayat al-Quran: Menilik Upaya Pemeliharaan al-Quran pada Masa Nabi dan Empat Sahabat Khulafa' Rasyidin,” Media Akad., vol. 28, no. 4, pp. 527-552, 2013.

[4] 'Umar Yusuf "Abd al-Ghani Hamdan, "Mashru' al-Masahif al-Thani fi al-'Asr al-Umawi," Majallat al-Buhuth wa al-Dirasat al-Quraniyyah, vol. 2, no. 4, 2004.

[5] A. ibn "Abd al-R. Al-Huzayfi, "A'mal Lajnah al-'Ilmiyyah bi-Mujamma' al-Malik Fahd liTiba'at al-Mushaf al-Sharif li-Muraja'at al-Mushaf al-Madinah al-Munawwarah," Majallat al-Buhuth wa al-Dirasat al-Quraniyyah, vol. 1, no. 7, 2000.

[6] E. Sudrajat, "Pentashihan Mushaf Al-Qur'an di Indonesia," Suhuf J. Pengkaj. Islam dan Budaya, vol. 6, no. 1, pp. 59-81, 2013.

[7] A. Hakim, "Pola Pestahihan Mushaf al-Quran di Indonesia: Benang Merah Institusi Pentashihan sebelum 1959," Suhuf J. Pengkaj. al-Quran dan Budaya, vol. 7, no. 1, pp. 23-38, 2014.

[8] Jayusman, "Pentashihan Buku Yasin sebagai Upaya Pemeliharaan Otentisitas al-Quran," Tapis J. Penelit. Ilm., vol. 11, no. 1, pp. 21-38, 2011.

[9] E. Babbie, The practice of social research. Boston: Cengage learning, 2016.

[10] Departemen Agama, Peraturan Menteri Agama Nomor 1 Tahun 1957 tentang Pengawasan terhadap Penerbitan dan Pemasukan al-Quran. 1957.

[11] Departemen Agama, Peraturan Menteri Muda Agama Nomor 11 Tahun 1959 tentang Lajnah Pentashih Mushaf Al-Qur'an. 1959.

[12] Machasin, "Prof. Mr. R.H.A. Soenarjo," in Lima Tokoh Pengembangan IAIN Sunan Kalijaga Yogyakarta, M. Damami, Ed. Yogyakarta: Pusat Penelitian IAIN Yogyakarta, 1998, pp. 95-96.

[13] Departemen Agama, Peraturan Menteri Agama Nomor 1 Tahun 1982 tentang Lajnah 
Pentashih Mushaf Al-Qur'an. 1982.

[14] Kementerian Agama, KMA Nomor 280 Tahun 2003 tentang Pembentukan Tim Penyempurnaan Al-Quran dan Tafsirnya. 2003.

[15] Kementerian Agama, Peraturan Menteri Agama Nomor 3 Tahun 2007 tentang Organisasi dan Tata Kerja Lajnah Pentashihan Mushaf Al-Qur'an. 2007.

[16] S. Osman, "Expressing Islam: A Study of Bayt al-Quran and Museum Istiqlal Indonesia and the Islamic Arts Museum Malaysia," National University of Singapore, 2011.

[17] Kementerian Agama, Peraturan Menteri Agama Nomor 44 Tahun 2016 tentang Penerbitan, Pentashihan dan Peredaran Mushaf Al-Quran. 2016.

[18] A. S. Muhammad, "Etika Penerbitan Al-Qur'an," Lajnah Pentashihan Mushaf Al-Qur'an, 2017. [Online]. Available: https://pmq.inuxpro.com/artikel/18-etika-penerbitan-al-qur-an-langkahlangkah-yang-perlu-diperhatikan-bagian-3. [Accessed: 18-Jul-2017].

[19] L. M. Putra, "Kementerian Agama Resmi Luncurkan Aplikasi Al Quran Digital Pertama," Kompas.com, 2016. .

[20] M. Hanafi, "Personal Communication," Apr-2018. 